\title{
Pelayanan dan Kepemimpinan Pendeta Perempuan BNKP
}

\author{
Women in Ministry and Leadership at BNKP Church
}

\author{
Otoriteit Dachi ${ }^{1}$, Vinna Isya Merti Manao ${ }^{2}$ \\ 12STT Banua Niha Keriso Protestan Sundermann Nias \\ ritterdachi@sttsundermann.ac.id
}

\section{ARTICLE INFO}

Submitted: September 4, 2021

Review: September 9, 2021

Accepted: October 6, 2021

Published: October 6, 2021

\section{KEYWORDS}

BNKP, female pastors, leadership, patriarchal culture

\section{CORRESPONDENCE}

Phone:

E-mail: ritterdachi@sttsundermann.ac.id

\begin{abstract}
A B S T R ACT
Today, women who are leaders have increased in almost all aspects of human life. Based on data from the BNKP Synod Office, the female pastors in BNKP experienced significant growth and development and even held positions as leaders in several institutions in the BNKP. On the other hand, Nias society adheres to a Patriarchal system where the role of men is always a priority. In the patriarchal cultural system, of course, the priest of women experiences various challenges both from within her internally regarding intellectual, emotional, and mental readiness and problems around her (external), namely the existence of the Congregation Councill and Elder, which men dominate. In some places, there are still congregations that reject women's leadership because of societal customs issues that limit women's wiggle room due to the patriarchal system embraced. In light of the above circumstances, the study explores how BNKP's female pastor develops her leadership potential in patriarchal culture by looking at the challenges and opportunities that exist both from the culture and the nature of the woman herself. In addition, it will also be presented about women's leadership styles to answer the current BNKP challenges. In this paper, researchers will use qualitative research methods, and data recorded in the field will be processed in such a way to be described.
\end{abstract}

\begin{abstract}
A B S T R A K
Pada masa sekarang ini kaum perempuan yang menjadi pemimpin sudah semakin meningkat di hampir semua aspek kehidupan manusia. Berdasarkan data yang ada di Kantor Sinode BNKP, pendeta perempuan di BNKP mengalami pertumbuhan dan perkembangan jumlah yang cukup signifikan, bahkan menduduki posisi sebagai pemimpin dalam beberapa lembaga di BNKP. Pada sisi lain masyarakat Nias menganut sistem Patriarkat dimana peran laki-laki selalu menjadi prioritas. Dalam sistem budaya patriarkat tentu pendeta perempuan mengalami berbagai tantangan baik dari dalam dirinya secara internal menyangkut kesiapan intelektual, emosional, dan mental maupun masalah di sekitar dirinya (eksternal), yaitu keberadaan majelis jemaat dan Satua Niha Keriso (Penatua) yang didominasi oleh kaum laki-laki. Di beberapa tempat masih ada jemaat yang menolak kepemimpinan perempuan karena masalah adat istiadat di masyarakat yang membatasi ruang gerak perempuan akibat sistem patriarkat yang dianut. Sehubungan dengan keadaan di atas, maka penelitian ini bertujuan untuk menggali bagaimana pendeta perempuan BNKP mengembangkan potensi kepemimpinannya dalam budaya patriarkat dengan melihat tantangan dan peluang yang ada baik dari budaya dan dari hakikat diri perempuan itu sendiri. Selain itu, akan dipaparkan juga tentang gaya kepemimpinan perempuan untuk menjawab tantangan BNKP saat ini.
\end{abstract}


Dalam tulisan ini peneliti menggunakan metode penelitian kualitatif dan data-data yang di rekam di lapangan akan diolah sedemikian rupa untuk kemudian dideskripsikan.

Kata kunci: BNKP, budaya patriarkat, kepemimpinan, pendeta perempuan

\section{PENDAHULUAN}

$\mathbf{K}$ aum perempuan saat ini sudah banyak terlibat dalam pengambilan keputusan dan telah menjadi pemimpin di berbagai lembaga seperti lembaga agama, ekonomi, politik maupun kemasyarakatan. Hal ini menunjukkan bahwa kaum perempuan memiliki potensi yang sama dengan kaum laki-laki dalam hal kepemimpinan.

Dalam gereja Kristen Protestan sendiri, sudah banyak gereja yang memperkenankan kaum perempuan untuk menjadi pendeta sekaligus memimpin organisasi dan pelayanan mulai dari aras jemaat hingga sinode. Beberapa sinode gereja di Indonesia yang telah mengakui penahbisan pendeta perempuan, seperti GMIT (Gereja Masehi Injili Timor), GPM (Gereja Protestan Maluku), BNKP (Banua Niha Keriso Protestan) HKBP (Huria Kristen Batak Protestan), GERMITA (Gereja Masehi Injili Talaud) dan beberapa sinode gereja lainnya.

Tidak bisa dipungkiri bahwa karena pemahaman teologi yang dianut oleh aliran gereja tertentu, khususnya di kalangan gereja Protestan sehingga belum menerima perempuan sebagai pendeta, seperti GKLI (Gereja Kristen Lutheran Indonesia), GITJ (Gereja Injili di Tanah Jawa), gereja Baptis dan Gereja Reform milik Stephen Tong.

Gereja BNKP adalah salah satu denominasi gereja yang menerima penahbisan pendeta perempuan dan mengakui mereka sebagai sesama pelayan sama seperti pendeta laki-laki. Pada sepuluh tahun terakhir jumah pendeta perempuan di BNKP, mengalami pertumbuhan yang sangat pesat. Bahkan sekarang ini menurut data di Sekretariat Kantor Sinode BNKP tahun 2021, dari 601 orang jumlah pendeta di BNKP, 300 orang di antaranya adalah pendeta perempuan dan 301 orang adalah laki-laki. Beberapa jemaat yang ada di BNKP lebih menyukai pendeta perempuan dengan alasan bahwa perempuan lebih rajin, teliti, dan sabar.

Pendeta perempuan telah menduduki beberapa jabatan penting di gereja BNKP, antara lain sebagai ketua majelis jemaat (pendeta jemaat), pendeta resort, kepala departemen, dosen di STT dan unit-unit pelayanan lainnya di BNKP. Dalam Persidangan Sinode BNKP tahun 2012, anggota Majelis Sinode sepakat memilih pendeta perempuan menjadi Sekretaris Umum BNKP.

Namun demikian, di tengah budaya Nias yang yang menganut sistem patriarkat, kepemimpinan dan pelayanan pendeta perempuan masih menemui berbagai tantangan dan hambatan baik dari dalam dirinya secara internal menyangkut kesiapan intelektual, emosional, dan mental, juga masalah di sekitar dirinya (eksternal), yaitu keadaan jemaat yang masih terbatas sumber daya dalam pelayanan, masih terdapat segelintir pelayan di jemaat yang menolak kepemimpinan dan pelayanan pendeta perempuan. Di samping itu ada juga masalah sosial kemasyarakatan seperti adat istiadat yang membatasi hal-hal tertentu kepada perempuan serta sistem budaya patriarkat yang dianut masyarakat khususnya Nias.

Selain masalah budaya, pendeta perempuan juga menghadapi kesulitan melayani di beberapa wilayah pelayanan, BNKP yang masih terisolir dengan kondisi kemiskinan dan rendahnya tingkat pendidikan warga jemaat dan pelayan gereja. Pendeta perempuan juga harus menjalankan fungsi ganda sebagai seorang pelayan dan ibu rumah tangga yang mengurus keluarga (suami, anak, dan anggota keluarga).

\section{Perempuan dalam Alkitab dan Gereja Mula- mula}

Jika melihat peranan perempuan dalam Alkitab, menunjukkan bahwa banyak perempuan menjadi tokoh terpenting dalam sejarah. Seperti dalam Perjanjian Lama dan 
Perjanjian Baru. ${ }^{1}$ Dalam Perjanjian Lama adanya kisah dua bidan yang biasa membantu persalinan perempuan Israel yaitu Pua dan Sifra, yang menentang perintah raja Firaun dengan tidak membunuh bayi laki-laki Israel (Keluaran 1:1-2:10).

Kisah Ester yang menjadi tokoh terpenting yang membebaskan bangsa Yahudi dari musuhmusuhnya di masa kepemimpinan raja Ahasyweros (Ester 1-10). Kisah Debora seorang nabiah, istri Lapidot memerintah sebagai hakim bagi Israel (Hak. 4), selain itu ada beberapa perempuan lain di Alkitab seperti Abigail, istri Nabal (yang bebal) yang kemudian menjadi istri Daud - seorang perempuan yang bijaksana, yang menyelamatkan seluruh keluarganya dari kehancuran yang akan didatangkan Daud atasnya. Dengan kelembutannya sebagai seorang perempuan, Abigail bisa mengurangi amarah Daud. ${ }^{2}$ Juga Ruth dan Naomi, istri Musa, Tamar dan para ibu leluhur Israel (Sara, Ribka, Lea, Rahel).

Dalam Perjanjian Baru ada banyak perempuan yang memiliki peranan penting, seperti Maria ibu Yesus, Elisabet, Maria Magdalena, dan banyak perempuan lainnya. Demikian halnya dalam surat Rasul Paulus, kita melihat bahwa Paulus tidak membatasi peranan serta makna kehadiran perempuan. Ia menyebut Febe sebagai "pelayan" (suatu fungsi yang penting pada saat itu), Roma 16:1-2. Yunias bersama Andronikus yang diakui sebagai "rasul", kemudian peranan Priskila bersama suaminya, Akwila (Roma 16:3-7).

Jelas sudah dari hal-hal di atas bahwa sebenarnya di dalam bayang-bayang patriarki yang begitu kuat satu sisi, maka di sisi lain juga secara tidak langsung Alkitab tampil dengan kisah-kisah yang menghadirkan budaya yang kontras berjuang melawan tradisi yang ada, bahkan menciptakan alternatif-alternatif. Oleh karena itu, perempuan harus memiliki keyakinan bahwa mereka mampu dan bisa bersinergi dengan para pemimpin laki-laki. Lakilaki bukan saingan melainkan mitra sejajar.

${ }^{1}$ Asnath N. Natar, ed., Perempuan Kristiani Indonesia Berteologi Feminis Dalam Konteks, 1st ed. (Jakarta: BPK Gunung Mulia, 2017), 125-132.

2 Basilica Dyah Putranti and Asnath N. Natar, eds., Perempuan, Konflik \& Rekonsiliasi: Perspektif Teologi Dan Praksis, 1st ed. (Jakarta: BPK Gunung Mulia, 2016), 115.

\section{Kepemimpinan Perempuan}

Secara numerik, kaum perempuan merupakan mayoritas. Hampir di mana-mana di dunia jumlah perempuan lebih banyak. Namun, dalam hal pengambilan keputusan kaum perempuan jelas merupakan minoritas. ${ }^{3}$

Perempuan sejak usia dininya, ia telah dibiasakan untuk memainkan peranan sebagai pihak yang tunduk dan sebagai bawahan. Statusnya selalu merupakan perolehan, tidak pernah primer. Ia bukan seorang pribadi dari dirinya sendiri, melainkan selalu ia merupakan "anak perempuan/istri/ibu" dari seorang lakilaki. ${ }^{4}$ Bahkan banyak orang, yang merasa bahwa seorang gadis harus diajar bagaimana memasak, bukan bagaimana untuk berpikir. Hal itu telah berlangsung sejak dahulu kala. Namun keberadaan peran perempuan kini mulai dihargai dan disetarakan.

Sejalan dengan gerakan emansipasi dan gerakan kesetaraan gender yang intinya berusaha menuntut adanya persamaan hak perempuan dalam berbagai bidang kehidupan, maka setahap demi setahap telah terjadi pergeseran dalam mempersepsi tentang sosok perempuan. Dalam kehidupan ekonomi, sudah lama kaum perempuan bisa mendapatkan tempat yang sederajat dengan kaum laki-laki.

Dalam dunia politik, kesadaran akan keadilan gender, akan kesetaraan laki- laki dan perempuan, tidak lagi hanya merupakan percakapan di lingkungan-lingkungan sempit, tetapi telah mendapat wujud dalam gerakan politik. Hal ini kelihatan, misalnya, dalam tuntutan keterwakilan perempuan di lembaga legislatif sebanyak 30\% sejak pemilu 2004. ${ }^{5}$ Peran perempuan dalam kehidupan bermasyarakat dalam pembangunan bukan hanya sebagai objek pembangunan, tetapi juga sebagai fondasi yang berstruktur kuat.

Mereka tidak dipandang lagi sebagai sosok lemah yang selalu berada pada garis belakang, namun mereka bisa tampil di garis depan sebagai pemimpin yang sukses dalam berbagai sektor kehidupan, yang selama ini justru dikuasai oleh

3 Marianne Katoppo, Compassionate And Free [Tersentuh Dan Bebas]: Teologi Seorang Perempuan Asia (Jakarta: Aksara Karunia, 2007), 4.

4 Ibid., 14.

5 Natar, Perempuan Kristiani Indonesia Berteologi Feminis Dalam Konteks. 
kaum laki-laki. Perempuan memiliki kemampuan yang sama untuk berada di posisi puncak dalam karier. Faktanya dalam berbagai organisasi saat ini termasuk dalam gereja, saat gaya kepemimpinan yang keras dan kaku tidak lagi sesuai untuk karyawan atau bawahan, namun gaya kepemimpinan perempuan yang komprehensif serta nilai-nilai positif lainnya membuat mereka lebih cocok untuk menduduki posisi puncak.

Berbicara tentang gaya kepemimpinan antara laki-laki dan perempuan, terdapat gaya kepemimpinan maskulin dan feminim. Pemimpin laki-laki cenderung memraktekkan gaya kepemimpinan maskulin yaitu bersikap tegas, cepat, efesien, mengacu pada tujuan, kurang memperhatikan aspek hubungan antar pribadi dan bersifat top-down. Sedangkan kaum perempuan lebih banyak mempraktekkan gaya kepemimpinan feminin, yaitu lemah-lembut, mendorong partisipasi, pembagian kekuasaan dan informasi, mempertimbangkan hubungan antar pribadi dan mempertinggikan harga diri orang-orang serta perempuan multitasking. ${ }^{6}$

Perempuan lebih memerhatikan keinginan bersama/orang lain dari pada keinginan pribadi demi mencapai tujuan organisasi. ${ }^{7}$ Ciri atau gaya kepemimpinan perempuan (feminin) adalah jaringan hubungan pribadi yang mendorong partisipasi, membagikan kekuasaan dan informasi, mengajak orang lain meningkatkan nilai pribadinya, dan memberi kesempatan kepada orang lain untuk merasa bangga atas pekerjaannya. Dalam kepemimpinan perempuan, pemberdayaan merupakan dasar berpijak. Pemberdayaan berarti perasaan percaya diri dan bekerja berdasarkan otoritas sendiri.

Model kepemimpinan perempuan bersifat melayani bukan menguasai (power over). Kekuasaan dipahami oleh perempuan sebagai power to, yaitu kekuasaan yang bersifat mendorong untuk kreatif sehingga berdaya. Kekuasaan juga dipahami sebagai power with, yaitu bagaimana semuanya disatukan untuk

${ }^{6}$ Carol Gilligan, Dalam Suara Yang Lain (Jakarta: Pustaka Tangga, 1997), 46.

7 Ibid., 59.

8 Asnath N. Natar, "Perempuan Dalam Kepemimpinan Agama: Pengalaman Kristen," Musãwa Jurnal Studi Gender dan Islam 18, no. 2 (July 30, 2019): 145, memecahkan masalah bersama, dan powerwithin yaitu kekuatan spiritual yang muncul dari hati manusia yang paling dalam (Murniati, 1996). ${ }^{8}$ Oleh karena itu, gaya kepemimpinan feminin dan maskulin sebenarnya harus dimiliki oleh setiap pemimpin sehingga kepemimpinannya berhasil dan berdampak baik bagi orang lain.

Secara umum ada dua gaya kepemimpinan khas perempuan yakni pertama, kepemimpinan maskulin-feminim dan kedua, kepemimpinan transformasional-transaksional. Gibson dalam Fitriani (2015) mendefinisikan kepemimpinan tranformasional sebagai kemampuan untuk memberikan inspirasi dan motivasi para pengikut untuk mencapai hasil yang lebih daripada yang direncanakan secara orisinal dan untuk imbalan internal. ${ }^{9}$ Sedangkan kepemimpinan transaksional adalah kepemimpinan yang melakukan transaksi memotivasi para pengikut dengan menyerukan kepentingan pribadi mereka (Burn, 1978)..$^{10}$

Perempuan memiliki sifat- sifat dasar untuk sukses sebagai pemimpin. Mereka cenderung lebih sabar, memiliki empati, mengandalkan relasi manusia dan multitasking - mampu melakukan beberapa hal sekaligus. Perempuan juga memiliki bakat untuk menjalin networking dan melakukan negosiasi. Hal ini, yang menjadi potensi perempuan yang dapat sukses memimpin dan mereka bisa diterima dan dipercayai. Namun, ada baiknya kalau gaya kepemimpinan maskulin dan feminin dikombinasikan dan disesuaikan dengan kelompok yang dipimpin. Jadi bukan hanya memraktekkan satu gaya kepemimpinan sebagai satu-satunya yang paling baik.

\section{Faktor Penghambat Kepemimpinan Perempuan}

1. Faktor Budaya. Pengaruh budaya patriarkat masih kuat, dimana laki-laki dianggap sebagai pemegang kuasa dan tempat berlindung, sementara kaum perempuan hanya berada di ruang domestik. Kemudian

http://ejournal.uinsuka.ac.id/pusat/MUSAWA/article /view/1970.

9 Annisa Fitriani, "Gaya Kepemimpinan Perempuan," TAPIS: Jurnal Teropong Aspirasi Politik Islam 11, no. 2 (2015): 1-24, http://ejournal.radenintan.ac.id/ index.php/TAPIs/article/view/845. 
masih dominan pandangan tradisional tentang pembagian tugas antara pria dan wanita. Pekerjaan rumah, mengasuh anak dianggap tugas wanita, dan pekerjaan itu menyita waktu banyak, sehingga para wanita hanya mempunyai sedikit kesempatan berperan di luar rumah/dalam masyarakat. Wanita berperan ganda. Peran ganda itu sendiri merupakan beban yang luar biasa beratnya bagi wanita, apalagi kalau tidak didukung oleh peran ganda pria sebagai co-partner yang saling mendukung. Hal ini menyebabkan pendeta mengalami kesulitan dalam menjalankan pelayanannya karena kurang mendapat dukungan dari keluarga terutama suami.

2. Faktor Diri sendiri. Selain karena budaya, saya melihat kurangnya peran dan keterlibatan perempuan dalam kepemimpinan gereja dan masyarakat juga datang dari kaum perempuan sendiri, baik diri sendiri maupun sesama perempuan. Perempuan merasa kurang percaya diri atau sebaliknya cepat puas diri. Sebagian perempuan tidak berniat menduduki jabatan struktural karena bagi mereka, melayani tidak harus dengan menjadi pejabat struktural, tetapi bisa juga melalui bidang pelayanan yang lain, seperti pelayanan sosial atau kategorial.

Sehubungan dengan berbagai persoalan sebagaimana diuraikan di atas, artikel ini bertujuan untuk menggali sejauhmana pendeta perempuan BNKP mengembangkan potensi kepemimpinannya dalam budaya patriarkat serta tantangan-tantangan lain yang dihadapinya. Selain itu, penulis akan mendesikripsikan langkah-langkah konkrit yang perlu dilakukan pendeta perempuan di BNKP agar mereka lebih mampu menghadapi tantangan kepemimpinan di dalam berbagai kondisi yang ada.

\section{METODE}

Untuk menghimpun informasi yang relevan dengan topik atau masalah yang dibahas dalam tulisan ini, penulis menggunakan metode penelitian deskriptif-kualitatif. Peneliti

${ }^{11}$ Majelis Sinode BNKP, Tata Gereja BNKP, 2007. melakukan penelaahan terhadap buku-buku dan dokumen yang berkaitan dengan masalah penelitian. Setelah itu, melakukan wawancara langsung kepada pendeta perempuan jemaat dan resort, tokoh budaya Nias, dan BPMJ, untuk mendapatkan informasi atau pendapat terkait tentang kepemimpinan pendeta perempuan BNKP dalam budaya patriarkat. Peneliti wawancarai 15 orang pendeta Jemaat, 4 orang pendeta Resort, 3 orang tokoh budaya Nias, 3 orang BPMJ, jadi sumber datanya berjumlah 25 orang. Beberapa alat bantu yang dapat mendukung berjalannya wawancara tersebut akan penulis gunakan, misalnya kamera, tape recorder, buku catatan dan pedoman wawancara. Setelah mengumpulkan informasi dan data-data dari hasil wawancara, maka akan dilakukan analisa sesuai dengan apa yang sudah ditemukan baik di lapangan maupun dari sember bacaan. Dalam menganalisis data dilakukan dengan tujuan untuk mengidentifikasi pola hubungan antara budaya patriakhat dengan kepemimpinan pendeta perempuan khususnya di gereja BNKP.

\section{HASIL DAN PEMBAHASAN}

Gereja BNKP menganut sistem Presbiterial Sinodal,11 yang menjadikan jemaat-jemaat sebagai basis pelayanan. Paham presbiterial sinodal dijelaskan dalam penjelasan tentang pokok gereja dan pemahaman iman BNKP yang menyatakan bahwa BNKP mengatur pelayanannya secara presbiterial sinodal, yakni suatu sistem kepemimpinan kolektif-kolegial yang dilakukan oleh para pendeta, Guru Jemaat, penatua, dan diaken. Hal ini dimaksudkan agar BNKP terhindar dari dominasi kepemimpinan dan pengambilan keputusan di tangan satua orang.

Struktur organisasi dan pelayanan BNKP adalah Jemaat-Resort-Sinode. Sistem presbiterial sinode yang merupakan gabungan dari sistem sinodal dengan presbiterian. Sistem ini memiliki ciri utama yaitu kepenuhan dalam kesatuan. Dalam sistem Presbiterial sinodal semua keputusan yang diambil berdasarkan kesepakatan bersama bukan berdasarkan wewenang yang ada pada satu pihak atau seseorang. ${ }^{12}$

12 BPMS-BNKP, Peraturan BNKP Nomor 07/BPMSBNKP/2008, Tentang PELAYAN (Kantor Sinode BNKP, 2008), 7-9. 
Sistem Presbiterial Sinode tercermin dalam kehidupan jemaat setempat sebagai berikut: "Majelis Jemaat adalah pengambil keputusan tertinggi karena berfungsi mencerminkan kesatuan dari keseluruhan anggota jemaat. Oleh karena itu sarana dalam pengambilan keputusan yang paling berwenang adalah Persidangan Majelis Jemaat."13

Corak dan sikap kepemimpinan terdapat dalam bentuk yang berbeda-beda terutama di kalangan pendeta. Perbedaan-perbedaan tersebut tersebut dapat digolongkan dalam 3 pola, yaitu:

a) Pola tradisionil yaitu pola kepemimpinan yang mempergunakan lebih banyak unsurunsur kebudayaan daerah dalam menyelesaikan persoalan, seperti peribahasa atau cerita-cerita di daerah yang mengandung arti kiasan. Unsur-unsur adat istiadat sering tidak dapat dipisahkan dari unsur-unsur gerejawi, sehingga fungsional-fungsional adat sering dominan dalam mengambil keputusan. serta fungsi kepemimpinan lebih dititikberatkan pada fungsi pemeliharaan, terutama pemeliharaan ketertiban, dan kurang memperhatikan fungsi pengembangan.

b) Pola yang bersifat otoriter-hierarkhis. Pola ini mirip dengan pola pemerintahan negara, memperlakukan peraturan-peraturan gereja seperti dengan undang-undang atau peraturan-peraturan pemerintah, persembahan-persembahan diperlakukan seperti "pajak gereja." Susunan kekuasaan kepemimpinan secara hierarkhis dari atas sampai ke bawah, di mana pimpinan tingkat atas (Ephorus dan pengurus besar) dianggap sebagai orangtua yang harus memperhatikan kesejahteraan anak-anaknya (jemaat) secara rohani dan materiel.

c) Pola semi modern, dengan unsur-unsur sebagai berikut: berusaha untuk menemukan kebutuhan gereja dan jemaat dengan inisiatif sendiri dan memimpin secara lebih rasionil dan progresif.

Melihat pola kepemimpinan di BNKP bahwa ada 4 corak kepemimpinan yang berlaku dalam BNKP yaitu: Kepemimpinan yang

13 Ibid. 108-127.

14 W. Gulo, Benih Yang Tumbuh 13 (Salatiga, 1983),

15 Ibid., 124-125. bercorak demokratis-modern-progresip; kepemimpinan yang bercorak demokratistradisional; kepemimpinan yang bercorak hierarkhis-birokrasi; dan kepemimpinan yang bercorak kharismatis. ${ }^{14}$ Namun, dari beberapa pola kepemimpin dalam BNKP menurut Ephorus S. Mendrofa pada sidang Sinode tahun 1971 bahwa corak kepemimpinan yang dikehendaki oleh BNKP adalah pertama, kepemimpinan yang kharismatis, dalam arti terbuka bagi dan dipenuhi oleh Roh Kudus. Kedua, kepemimpinan kolegial, yang menjamin kerukunan di antara sesama pelayan. Ketiga, kepemimpinan yang edukatif, dan keempat, kepemimpinan yang modern yang sanggup melaksanakan pembaharuan dan kemajuan dalam jemaat dan masyarakat setempat. ${ }^{15}$

\section{Pendeta di BNKP}

Dalam Peraturan BNKP Nomor 07/tahun 2008, pasal 6 mengatakan bahwa pendeta adalah seseorang yang telah dipanggil dan dipilih Tuhan serta kepadanya dipercayakan untuk melayani Firman Allah sesuai dengan kesaksian Alkitab dan peraturan BNKP. Dan dalam pasal 5 dikatakan bahwa kependetaan adalah suatu cara dan bentuk pelayanan Firman Allah oleh gereja yang dipercayakan kepada seseorang sesuai dengan kesaksian Alkitab dan peraturan BNKP. ${ }^{16}$ Oleh karena itu, tugas pokok pendeta adalah memberitakan Firman Tuhan, melayankan Sakramen, menyelenggarakan pengajaran serta menjalankan tugas-tugas pastoral di tengah jemaat. Di samping itu pendeta bertanggungjawab memelihara kesatuan jemaat. Hal ini senada dengan tugas dan fungsi pelayan dalam Alkitab sebagai gembala yang melayani domba-domba (Yohanes 10, 1 Petrus pasal 5). Istilah pendeta adalah pelayan, gembala atau gembala sidang yang memiliki makna pemimpin jemaat dan menjadi penatalayanan yang harus melayani jemaat (leadership is ministry). ${ }^{17}$

\section{Fungsi, Tugas dan Tanggung Jawab Pendeta di BNKP}

Dalam Peraturan BNKP Nomor 07 Tahun 2008, diuraikan bahwa tugas utama Pendeta

16 BPMS-BNKP, Peraturan BNKP Nomor 07/BPMSBNKP/2008, Tentang PELAYAN, 5-6.

17 A. Maitimoe, "Kepemimpinan Yang Melayani," Ministerium Buletin Teologi Gereja (Jakarta, 2003), 81. 
adalah pemberita Firman Tuhan, pelayan sakramen baptisan, sakramen penjamuan kudus, layanan pastoral, peneguhan sidi, peneguhan/ penahbisan para pelayan, pemberkatan pernikahan, penguburan orang mati. ${ }^{18}$ Pendeta berdiri sebagai wakil Allah terhadap umat-Nya untuk menjaga dan memelihara mereka dan pendeta juga bertanggung jawab dalam penyelenggaraan fungsi manajemen dan organisasi jemaat, mulai dari perumusan visi, misi, tujuan, dan strategi program jemaat dan bersama dengan majelis jemaat (penatua dan diaken) memimpin pelaksanaan program dan mengevaluasi kegiatan yang telah dilaksanakan.

\section{Perempuan sebagai Pendeta di BNKP}

Masuknya sejarah modernisasi, emansipasi perempuan dan pengaruh budaya barat ke Indonesia menyebabkan adanya pergeseran kedudukan dan relasi gender, termasuk dalam gereja. Tuntutan adanya kesetaraan antara lakilaki dan perempuan merupakan penyebab utama dalam pergeseran kedudukan dan relasi gender tersebut. Salah satu lembaga yang merespon positif pada konsep kesetaraan tersebut adalah gereja BNKP. Gereja ini memberikan dukungan penuh terhadap perempuan untuk menduduki posisi atau peran strategis dalam lembaganya sebagai seorang pendeta sekaligus memimpin dalam jemaat.

Bagi kaum perempuan, pada awalnya menjadi seorang pendeta dalam gereja BNKP tidak didapatkan dengan cara yang mudah, terdapat serangkaian proses yang cukup berat dalam membangun pemahaman masyarakat mengenai citra dan peran perempuan yang dianggap lemah dan tidak bisa menjadi pemimpin. Mengingat BNKP adalah gereja yang warga gerejanya berasal dari suku Nias yang menganut sistem patriarkat, sehingga cenderung mempengaruhi perspektif pendeta perempuan sebagai pemimpin. ${ }^{19}$ Dalam konteks gereja seperti inilah, pendeta perempuan menghadapi berbagai tantangan dalam playanan dan kepemimpinan dalam jemaat di BNKP. Oleh karena itu pendeta perempuan perlu membenahi dirinya dan kepemimpinannya, agar ia dapat

18 BPMS-BNKP, Peraturan BNKP Nomor 07/BPMSBNKP/2008, Tentang PELAYAN, 5-6.

19 Sistem patriarkat secara sederhana diartikan sebagai suatu sistem sosial yang menempatkan laki-laki lebih berkuasa dibanding perempuan. melakukan tugas-tugas kependetaannya sejajar dengan kaum laki-laki.

\section{Sejarah Kepemimpinan Pendeta Perempuan BNKP}

\subsection{Perempuan Nias sebelum Masuknya Injil}

Sebelum masuknya Injil, perempuan Nias tidak dapat memasuki wilayah publik, tidak boleh berbicara di dalam pertemuan-pertemuan umum, misalnya ikut dalam mengambil sebuah keputusan yang berkenaan dengan adat, apalagi menjadi seorang pemimpin. Jika seorang perempuan berani memasuki wilayah publik maka ia akan mendapatkan cemooh, hinaan, makian dari orang banyak.

Kebebasan kaum perempuan dibatasi oleh norma-norma adat, sehingga banyak perempuan Nias yang tidak berpendidikan, bahkan dipaksa nikah di bawah umur, tidak boleh ini tidak boleh itu, seperti istilah dalam bahasa Nias "Oya zitebai-tebai manö ba Nono Niha." Dengan demikian perempuan Nias sangat tertutup dan hanya berada dalam ruang domestik. Mereka tidak dapat menunjukkan potensi yang mereka miliki dan tidak mendapatkan kebebasan hakhaknya. Mereka hanya seorang perempuan yang tunduk dan pelaksana dari apa yang dikatakan oleh kaum laki-laki.

\subsection{Gerak Perempuan Nias setelah Masuknya Injil}

Ludwig Erns Denninger, seorang berkebangsaan Jerman, pada tanggal 27 September 1865 menginjakkan kaki di pulau Nias. Ia adalah misionaris perintis masuknya berita Injil di Nias. Kedatangannya di Nias senantiasa diperingati sebagai hari ulang tahun gereja-gereja Protestan di Nias secara khusus gereja BNKP. ${ }^{20}$

Berita Injil yang dibawa oleh Denninger dan beberapa penginjil lainnya dari badan misionaris RMG telah membawa perubahan dalam hidup masyarakat dan secara khusus bagi kaum perempuan Nias. Prinsip zending yang menegaskan bahwa setiap manusia berhak mendapatkan pembaruan di dalam Injil, baik itu lakilaki maupun perempuan, anak-anak maupun orang

20 BPMS-BNKP, Peraturan BNKP Nomor 07/BPMSBNKP/2008, Tentang PELAYAN. 
tua. Hal inilah yang membuat perempuan Nias terbebas dan memperoleh tempat dan peran yang sama dengan laki-laki dalam hal-hal tertentu seperti menjadi pelayan gereja.

Sejak terjadinya pertobatan massal (fangesa dödö sebua) yang berlangsung di tahun 1915-1930 telah membawa perubahan dalam hidup orangorang Nias terutama hak dan kebebasan seorang perempuan. Perempuan mulai dibebaskan dari struktur tradisional, mulai dihormati dan mendapatkan kesempatan untuk menikmati pendidikan. Setelah pertobatan massal perempuan yang menjadi murid sekolah misi mengalami peningkatan. Perubahan ini tidak mudah terjadi namun karena adanya peran istri para misionaris membuat perempuan Nias secara pelahan-lahan terbebas dari berbagai ikatan yang membelenggu keberadaan kaum perempuan.

Sebagai contoh, Wilhelmina Thomas, istri Wilhlem Thomas yang berusaha menarik hati kaum perempuan untuk mengikuti ibadah minggu, dengan menjahit baju mereka. ${ }^{21}$ Berkat upaya Wilhelmina Thomas, perempuan dan anak-anak, yang secara tradisional kurang mendapat tempat dalam masyarakat Nias, mendapat perhatian. Kaum perempuan mulai mengunjungi pos zending. Bekerja sama dengan Guru Jonatha, Wilhelmina memulai sebuah sekolah minggu. ${ }^{22}$ Pauline Garschagen, istri Friedrich Kramer melakukan pelayanan di antara perempuan Nias. ${ }^{23}$ Kemudian Dora, istri Lett yang tiba di bulan Desember 1892, menarik hati banyak perempuan ke pos zending. ${ }^{24}$

Fries membaptis Sariani putri salawa Baho dari Sifaoro'asi (Nias Tengah) yang merupakan murid katekisasi. Setelah dibaptis, Sariani menjadi saksi Kristus di Holi. Contoh lainnya dari pelayanan Misionaris Schlipkoter di Hilimaziaya Nias Utara. Schlipkoter juga menolong beberapa janda yang akan dijual setelah suami mereka meninggal. Mereka kemudian mengikuti pelajaran katekisasi dan menjadi Kristen.

21 Tuhoni Telaumbanua and Uwe Hummel, Salib Dan Adu: Studi Sejarah Dan Sosial-Budaya Perjumpaan Kekristenan Dan Kebudayaan Asli Di Nias Dan Pulau-Pulau Batu, Indonesia (1865-1965) (Jakarta: BPK Gunung Mulia, 2015), 116.

22 Ibid., 118.

23 Ibid., 105.
Di pulau-pulau Batu, khususnya di Sigata, Misionaris Landwehr dan istri memberi pelatihan bagi kaum perempuan. Dari pelatihan yang dilakukan, banyak dari peserta pelatihan itu kemudian turut mengabdi di pelayanan zending, salah satu dari mereka adalah Fija Fanaetu. Semula ia dilarang untuk menjadi Kristen oleh kepala sukunya yang bernama Farono yang sangat membenci kekristenan. Namun, Fija Fanaetu tidak menyerah; dia dibaptis dan menjadi tulang punggung komunitas Kristen di Sigata. ${ }^{25}$

Hal ini, menunjukkan bahwa para misionaris dengan istri mereka telah membawa pembebasan bagi perempuan dan memberi pengajaran tentang Alkitab, cara berdoa serta berbagai keterampilan rumah tangga sehingga perempuan Nias bisa menunjukkan jati dirinya yang selama ini terbelenggu oleh budaya tradisi dan budaya.

Usaha para misionaris tidak hanya sampai di situ, bahkan mereka juga membuka pelayanan pendidikan bagi kaum perempuan Nias. Pada tanggal 1 Juli 1931, sekolah menengah untuk putri, yang dipimpin oleh dua orang suster zending yaitu Hanna Blindow dan Emilie Rosenberg, dibuka untuk 41 orang murid. Murid yang bersekolah tidak pernah lebih dari 56 orang. Sehingga sekolah ini terpaksa di tutup karena Perang Dunia II. ${ }^{26}$ Sekolah itu disebut Meisjesvervolgschool yang berada di Gunungsitoli.

Kemudian terbukanya SMP pada tahun 1948, disusul dengan SGB, dan SKP yang telah membuka peluang bagi perempuan untuk melepaskan diri dari tradisi adat yang selama ini mengekangnya. ${ }^{27}$

Tahun 1958 gereja BNKP mendirikan Kursus Wanita Kristen (KWK), kegiatan ini telah banyak memberi kontribusi terhadap kemajuan perempuan Nias. Komisi Wanita (sekarang berubah nama menjadi komisi perempuan) mengutus dan menyediakan beasiswa kepada perempuan Nias, antara lain, Pdt. Nurlia Ziliwu

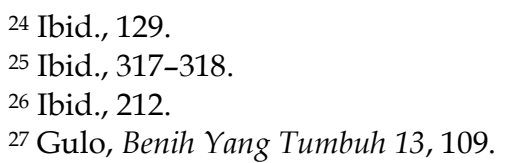


dan Pdt. Nilamwati Zendrato, untuk mengikuti pendidikan Teologi di institut Teologi Alkitab (ITA), di Bandar Baru, Sumatera Utara, pada tahun 1987, dengan tujuan meningkatkan pelayanan di kalangan perempuan gereja. ${ }^{28}$ Selain itu, BNKP terus mengorganisasi kelompok masyarakat khususnya kaum perempuan untuk mendirikan CU (credit union) atau koperasi, sebagaimana yang sudah ada sekarang ini. ${ }^{29}$

BNKP terus melakukan pembinaan bagi perempuan Nias dalam meningkatkan peranan perempuan baik dalam rumah tangga, maupun di tengah masyarakat dan gereja, terutama dalam mengatasi kekerasan dalam rumah tangga, pembinaan generasi muda, dan dalam memerangi kemiskinan. Kegiatan yang pernah dilakukan antara lain melaksanakan "Konsultasi Perempuan se-BNKP" pada tanggal 13-15 November 2013 di gereja BNKP Jemaat Mo'awö, Resort 1. Departemen Marturia terus melaksanakan pelatihan/penyuluhan tentang kesetaraan gender. ${ }^{30}$

\subsection{Perempuan Nias Ditahbiskan menjadi Pendeta di BNKP}

Sejak keputusan persidangan sinode BNKP yang ke-29 di Ombölata tahun 1964 telah ditetapkan Peraturan Kependetaan yang menyatakan bahwa jabatan pendeta di BNKP tidak didasarkan pada perbedaan gender. Namun peraturan itu mengalami perubahan sehingga baru pada tahun 2004 BNKP melakukan perubahan atas peraturan kependetaan di BNKP yang disusun pada tahun 1976.31 Di dalam peraturan itu semakin dipertegas siapa yang dapat ditahbis menjadi pendeta di BNKP. Pendeta yang dimaksudkan dalam peraturan ini, ialah seseorang yang telah dipercayakan melayani Firman Allah sesuai dengan kesaksian Alkitab dan peraturan yang berlaku di BNKP tanpa ada perbedaan jenis kelamin. Syarat-syarat untuk diangkat menjadi pendeta di BNKP, yaitu: ${ }^{32}$

Pertama, dalam kehidupan sehari-hari menunjukkan kesetiaan dan penyerahan diri kepada Yesus Kristus dan kepada pelayanan

28 Elvilina Hulu, "Penahbisan Perempuan Di Dalam Gereja-Gereja Protestan, Khususnya BNKP Dan GGBI" (Sekolah Tinggi Teologi Jakarta, 2008), 114.

29 BPHMS-BNKP, Hasil Rumusan Persidangan

Majelis Sinode BNKP Ke-58 (Gunungsitoli, 2007), 348.

30 Ibid., 125-126. jemaat hidup menurut buah- buah Roh (Gal 5:2223). Kedua, telah menempuh pendidikan teologi yang tidak bertentangan dengan pengakuan Iman Rasuli yang diterima dan diakui oleh BNKP. Ketiga, telah menempuh latihan persiapan kependetaan (masa vikariat) dan dinyatakan lulus, menurut ketentuan yang berlaku di BNKP. Keempat, telah menerima tahbisan sebagai Pendeta baik di gereja BNKP maupun gereja lain yang berada di bawah naugan PGI. Kelima, memiliki kemampuan jasmani dan rohani untuk menghadapi tuntutan dari tugasnya sebagai pendeta. Keenam, berumur serendah-rendahnya 24 tahun dan setinggi-tingginya 40 tahun. Ketujuh, memberikan pernyataan tertulis bahwa ia bersedia melayani di mana dia ditempatkan dan mematuhi segala peraturan yang berlaku di BNKP.

Melalui peraturan kependetaan di atas menunjukkan bahwa BNKP mengakui dan menerima laki-laki dan perempuan memiliki hak yang sama untuk menjadi pendeta dalam pelayanan gerejawi sebagai pelayan yang ditahbiskan.

Pada tanggal 14 Juli 1978 BNKP melakukan penahbisan pertama sekali atas perempuan menjadi pendeta BNKP di gedung gereja BNKP jemaat Gunungsitoli. Ephorus pada waktu itu adalah Pdt. B. Chr. Hulu (periode 1976 s.d. 1984). Tetapi penahbisan itu tidak dilakukan terhadap perempuan Nias, melainkan terhadap perempuan di luar suku Nias yang bersedia melayani di BNKP, yaitu F. M. Martawati, seorang perempuan Bali, yang telah menikah dengan Saroli Gulö, seorang laki-laki calon pendeta di BNKP. Namun, pendeta Martawati tidak ditempatkan di jemaat, justru di Lembaga Percetakan Literatur Gereja (LPLG), sebagai guru di sekolah dan memimpin ibadah minggu di jemaat-jemaat, dll. Ia tidak ditempatkan di jemaat karena masyarakat Nias tidak ingin dipimpin oleh seorang perempuan alasan budaya. Orang Nias masih memandang perempuan adalah makhluk lemah dan tidak bisa memimpin dan perempuan. ${ }^{33}$

${ }^{31} \mathrm{Hulu}$, "Penahbisan Perempuan Di Dalam GerejaGereja Protestan, Khususnya BNKP Dan GGBI," 108.

32 BPMS-BNKP, Peraturan BNKP Nomor 07/BPMSBNKP/2008, Tentang PELAYAN.

${ }^{3}$ Hulu, "Penahbisan Perempuan Di Dalam GerejaGereja Protestan, Khususnya BNKP Dan GGBI," 115-116. 
Kemudian, pada tanggal 22 April 1990 akhir abad ke-20 perempuan Nias ditahbiskan menjadi pendeta di BNKP, yaitu Ibahati Manaö menjadi pendeta perempuan Nias yang pertama di BNKP di gedung gereja BNKP jemaat Tumöri. Pada waktu itu yang menjadi Ephorus adalah Pdt. Fat. Zega (periode 1984 s.d. 1992). perempuan di BNKP. Pdt. Nilam pernah menjadi pemimpin asrama panti asuhan distrik komisi perempuan di Pulau Tello selama 6 tahun. Pdt. Nilam baru menjadi pendeta jemaat pada tahun 1998 di Jemaat Lalai [Pdt. Nilamwati Zendrato, Wawancara, 2021].

Tabel 1

Data Resort/Jemaat/Jumlah Jiwa di BNKP

\begin{tabular}{lll}
\hline Uraian & Jumlah & Keterangan \\
Warga Jemaat & 452.920 jiwa & \\
Resort & 60 Resort & \\
Jemaat & 1.102 Jemaat & Data Bulan Juni 2021, jumlah \\
Pendeta & 606 orang $(\mathrm{Lk}=304, \mathrm{Pr}=302)$ & $\begin{array}{l}\text { pendeta601 orang, Lk }=301, \operatorname{Pr}= \\
300 \text { orang }\end{array}$ \\
& & \\
AKP & 61 orang $(\mathrm{Lk}=21, \operatorname{Pr}=40)$ & \\
\hline
\end{tabular}

Sumber: Sekretariat Sinode BNKP

Sama seperti pendeta perempuan sebelumnya tidak diangkat sebagai pendeta jemaat. Ia justru diangkat sebagai pembina Kursus Wanita Kristen (KWK) Maranatha di Nari-nari. Begitu juga yang dialami oleh pendeta Nilamwati Zendratö bersama Nurlia Ziliwu yang ditahbiskan pada tahun 1992, mereka tidak
Pada tahun 1996 BNKP menempatkan Pdt. Miseria Daeli menjadi pendeta perempuan pertama yang ditempatkan sebagai pendeta yang melayani di jemaat BNKP jemaat Sihare'ö, Distrik BNKP Laraga. Pemimpin BNKP memilih jemaat ini sebagai jemaat pertama di tempatkan pendeta perempuan karena anggota jemaatnya

Tabel 2

Data Resort/Jemaat/Jumlah Jiwa di BNKP

\begin{tabular}{lrl}
\hline Unsur & Jumlah & Keterangan \\
Pendeta Emeritus & - & \\
Pendeta Resort & 6 Orang & \\
Pendeta Jemaat & 215 Orang & \\
Pendeta Fungsional & 31 Orang & \\
Pendeta Aktif Melayani di Unit Pelayanan & 4 Orang & Dosen STT BNKP Sundermann \\
& 7 Orang & Pegawai Kantor Sinode BNKP \\
Melayani di Instansi Pemerintah/Lain & 12 Orang & PNS \\
& 1 Orang & Kepala Sekolah [Yayasan] \\
Studi Lanjut (S2) & 2 Orang & \\
Studi Lanjut (S3) & 3 Orang & \\
Menunggu Penempatan & 17 Orang & 14 Permintaan sendiri \\
& & 1 Perpindahan \\
& & 1 Menunggu perpindahan \\
Misionaris/Tenaga Utusan & 2 Orang & \\
Vikar (2020-2021) & 25 Orang & \\
\hline
\end{tabular}

Sumber: Sekretariat Sinode BNKP

diangkat menjadi pendeta jemaat. Mereka ditempatkan di unit-unit pelayanan yang berkaitan dengan pelayanan bagi kaum mayoritas orang-orang berpendidikan dan terbuka terhadap pelayanan pendeta perempuan. Hal ini terbukti dengan besarnya 
antusiasme jemaat Sihare'ö menyambut pendeta Miseria Daeli. Serta sesuai pengalaman pendeta Miseria Daeli bahwa selama ia melayani disana ia tidak mengalami penolakkan dari jemaat sehingga ia dapat menyelesaikan 1 periode selama 5 tahun di sana [Pdt. Miseria Daeli, Wawancara, 2021].

Setelah penempatan pendeta perempuan di jemaat, maka disusul dengan penempatan pendeta-pendeta perempuan lainnya di jemaat dan di distrik/resort BNKP, menjadi Ketua Majelis Jemaat maupun Ketua Majelis Distrik yang sekarang Resort. Kemajuan ini membuktikan bahwa masyarakat Nias sudah terbuka kepada kepemimpinan pendeta perempuan di dalam jemaat dan resort. Bahkan sekarang ada beberapa jemaat yang lebih menginginkan pendeta perempuan sebagai pendeta jemaat mereka.

Walaupun dalam sejarah gereja tidak dikenal dengan istilah "Ibu-ibu gereja" (Church Mothers). Sebab yang ada hanya istilah "Bapakbapak gereja" (Church Fathers). Namun, keberadaan perempuan dalam gereja mengalami banyak kemajuan, dalam kalangan gereja-gereja Protestan telah menerima kedudukan perempuan dengan menahbiskan mereka dalam jabatan pendeta (priest) bahkan sampai ke uskup. Keadaan berbagai gereja Protestan di dunia dalam memberi status atau kedudukan pada kaum perempuan juga bermacam-macam. Salah satu dari gereja Protestan yang menerima kedudukan perempuan di dalam berbagai bidang, yaitu gereja BNKP.

Memang menjadi perempuan yang memimpin di BNKP tidak mudah bahkan membutuhkan proses yang panjang. 72 tahun lamanya BNKP melakukan pembagian kerja menurut jenis kelamin yang berakar dalam sistem patriarkat. Ada ikatan yang kuat dengan gereja, BNKP mencerminkan norma dan nilai masyarakat di sekitarnya. Dalam masyarakat Nias yang patriarkat posisi perempuan tidak setara dengan posisi laki-laki, perempuan tidak boleh menjadi pemimpin di dalam masyarakat, perempuan tidak boleh ambil bagian dalam mengambil keputusan yang berkenan dengan adat. Tetapi setelah peraturan di BNKP mengizinkan perempuan menjadi pendeta, hal ini menunjukkan bahwa BNKP dan masyarakat Nias menghargai pendeta perempuan sebagai pelayan-pelayan Kristus yang sepadan dengan laki-laki.

Dari uraian di atas menunjukkan bahwa sekarang ini terdapat 601 pendeta di BNKP yang sedang aktif melayani baik sebagai pendeta jemaat, resort, fungsional, maupun yang berada di unit pelayanan di BNKP. Terutama pendeta perempuan yang sudah banyak mendapatkan tempat sebagai pemimpin di jemaat, resort maupun di sinode dan di unit-unit pelayanan lainnya. Namun, di tengah perkembangan yang dialami oleh pendeta perempuan, mereka juga tengah mengalami berbagai tantangan yang dapat menjadi penghambat pelayanan mereka, yaitu:

a. Tantangan dari dalam dirinya secara internal yang meliputi kesiapan intelektual, emosional, dan mental menghadapi anggota Majelis Jemaat dan Penatua yang didominasi oleh kaum laki-laki. Di samping itu, kodratnya sebagai perempuan yang melahirkan, menyusui serta merawat anakanaknya menjadi tantangan tersendiri pendeta perempuan.

b. Tantangan secara (eksternal), yaitu keadaan jemaat yang masih terbatas sumber daya dalam pelayanan, adanya beberapa jemaat yang menolak kepemimpinan perempuan.

c. Tantangan dari sistem budaya patriarkat yang dianut masyarakat Nias, yang membatasi halhal tertentu kepada perempuan.

d. Tantangan medan pelayanan, di mana sebagian besar jemaat-jemaat di BNKP belum dilalui oleh kendaraan roda dua dan empat serta sulitnya komunikasi.

Dapat dikatakan bahwa pendeta perempuan menghadapi banyak tantangan dan beban yang lebih berat dibanding rekan kerja mereka laki-laki. Kondisi ini dapat menjadi alasan dari beberapa jemaat yang menolak pendeta perempuan diterima di jemaat. Dengan berbagai tantangan dan situasi seperti ini kepada pendeta perempuan dituntut untuk lebih meningkatkan kualitas pelayanan dan kepemimpinannya.

\section{KONKLUSI}

Era kebangkitan pendeta perempuan di BNKP, merupakan peristiwa yang menggembirakan dimana kepemimpinan dan pelayanan pendeta perempuan diterima dan 
diakui sebagaimana mestinya pendeta laki-laki pada. Pendeta perempuan mendapatkan tempat dan dapat melayani sebagai pemimpin. Hal ini, tidak pernah lepas dari kesadaran BNKP bahwa laki-laki dan perempuan setara dan sebagai pelayan yang sejajar dan sederajat.

Kebangiktan perempuan BNKP ini merupakan salah satu sumbangsih gereja BNKP yang memerdekakan kaum perempuan Nias dari belenggu adat dan tradisi yang masih terus dipertahankan khsusnya sistem Patriakat yang membatasi ruang gerak perempuan Nias.

Pada sisi yang lain dengan dibukanya ikatan adat dan tradisi yang membelenggu kaum perempuan, suatu gambaran jelas bahwa kaum perempuan Nias memiliki potensi besar dalam pembangunan jemaat serta dapat menunaikan tugas pelayanan dan kepemimpinan gereja dengan baik sama dengan laki-laki.

Dengan disejajarkannya laki-laki dan perempuan dalam peraturan kependetaan di $\mathrm{BNKP}$, telah mendorong perkembangan BNKP ke arah yang lebih baik dan dewasa karena peran yang dilakoni oleh pendeta perempuan dalam pelayanan, sering tidak bisa dilakukan oleh pendeta laki-laki.

Walaupun beban pelayanan dan kepemimpinan pendeta perempuan lebih berat dari pendeta laki-laki karena kodrat dirinya sebagai perempuan, namun dalam hal membangun dan mensukseskan pelayanan di jemaat, pendeta perempuan tidak kalah dibanding dengan pendeta laki-laki. Bahkan beberapa jemaat mengharapkan pendeta perempuan melayani mereka karena dianggap lebih rajin, sabar dan penuh perhatian.

Di masa depan diharapkan pendeta perempuan terus mengembangkan diri dan gaya kepemimpinan yang sesuai konteks budaya yang ada sehingga dapat meningkatkan misi pelayanan gereja BNKP baik di dalam dan juga keluar.

Di era teknologi 4.0 atau era digital ini, pendeta perempuan harus bisa mengembangkan model kepemimpinan sesuai tuntutan zaman. Pemimpin perempuan perlu membangun visi dan misi yang jelas, berani mengambil resiko, membangun jaringan relasi, memiliki kemampuan berkomunikasi secara efektif, tekun dan mampu membangun iklim kerja yang baik.
Perempuan harus memiliki keyakinan bahwa mereka mampu dan bisa bersinergi dengan para pemimpin laki-laki. Laki-laki bukan saingan melainkan mitra sejajar.

\section{REFERENSI}

BNKP, Majelis Sinode. Tata Gereja BNKP, 2007.

BPHMS-BNKP. Hasil Rumusan Persidangan Majelis Sinode BNKP Ke-58. Gunungsitoli, 2007.

BPMS-BNKP. Peraturan BNKP Nomor 07/BPMSBNKP/2008, Tentang PELAYAN. Kantor Sinode BNKP, 2008.

Fitriani, Annisa. "Gaya Kepemimpinan Perempuan." TAPIS: Jurnal Teropong Aspirasi Politik Islam 11, no. 2 (2015): 1-24. http:// ejournal.radenintan.ac.id/index.php/ TAPIs/article/view/845.

Gilligan, Carol. Dalam Suara Yang Lain. Jakarta: Pustaka Tangga, 1997.

Gulo, W. Benih Yang Tumbuh 13. Salatiga, 1983.

Hulu, Elvilina. "Penahbisan Perempuan Di Dalam Gereja-Gereja Protestan, Khususnya BNKP Dan GGBI." Sekolah Tinggi Teologi Jakarta, 2008.

Katoppo, Marianne. Compassionate And Free [Tersentuh Dan Bebas]: Teologi Seorang Perempuan Asia. Jakarta: Aksara Karunia, 2007.

Maitimoe, A. "Kepemimpinan Yang Melayani." Ministerium Buletin Teologi Gereja. Jakarta, 2003.

Natar, Asnath N. "Perempuan Dalam Kepemimpinan Agama: Pengalaman Kristen." Musãwa Jurnal Studi Gender dan Islam 18, no. 2 (July 30, 2019): 133. http://ejournal.uinsuka.ac.id/pusat/MUSAWA/article/view/1 970.

- - - , ed. Perempuan Kristiani Indonesia Berteologi Feminis Dalam Konteks. 1st ed. Jakarta: BPK Gunung Mulia, 2017.

Putranti, Basilica Dyah, and Asnath N. Natar, eds. Perempuan, Konflik \& Rekonsiliasi: Perspektif Teologi Dan Praksis. 1st ed. Jakarta: BPK Gunung Mulia, 2016.

Telaumbanua, Tuhoni, and Uwe Hummel. Salib Dan Adu: Studi Sejarah Dan Sosial-Budaya Perjumpaan Kekristenan Dan Kebudayaan Asli Di Nias Dan Pulau-Pulau Batu, Indonesia (18651965). Jakarta: BPK Gunung Mulia, 2015. 